\title{
ÉPÜLETKUTATÁS ÉS ÉPÍTÉSZETTÖRTÉNET - NÉHÁNY ÚJKORI ÉS 19. SZÁZADI ÉPÜLETTÍPUS KUTATÁSÁNAK MÓDSZERTANA ÉS EREDMÉNYEI
}

\author{
HABILITÁCIÓS TÉZISEK ${ }^{1}$
}

\author{
KRÄHLING JÁNOS \\ Dr. habil., tanszékvezető egyetemi docens. BME Építészettörténeti és Mủemléki Tanszék, \\ 1111 Budapest, Mủegyetem rkp. 3. K II. 82. Tel.: (+36-1) 463-1330. E-mail: krahling@eptort.bme.hu
}

\begin{abstract}
A címben megidézett kapcsolat a történeti épületkutatás és az építészettörténet között már sok kutatót foglalkoztatott. ${ }^{2}$ Téziseimben az újkori és 19. századi épülettípusokra vonatkozó vizsgálódásaim során alkalmazott kutatási alapelveket és módszereket kívánom a hazai és nemzetközi szakirodalom összefüggéseinek áttekintésével és kritikájával összegezni, értelmezni, bemutatva és pontokba rendezve a módszertan alkalmazásával elért eredményeimet.

Kiválasztott tíz publikációm alapján megfogalmazott öt tézis az építészeti kutatás különböző léptékeit és értelmezési lehetőségeit mutatja be öt különbözö kérdésfelvetés példájával. Mind az öt példában fontos szerepet kap az épületkutatás módszertana a maga sajátos interdiszciplináris megközelítésében, a történeti írott és képi források elemzésével és az azzal szorosan összefüggő épületfelméréssel: az objektumcentrikus, részletkérdésekben elmélyült, egy épületre koncentráló „Bauforschung” szemléletü, ${ }^{3}$ alakhü felmérésen alapuló kutatástól a regionális-területi szintủ építészeti jelenségeket átfogni képes, kisebb léptékủ tipológiai és topográfiai kutatáson át az építészet társadalmi vonatkozásait érintő kulturális identitáskérdések megválaszolásáig.
\end{abstract}

Kulcsszavak: történeti épületkutatás, Bauforschung, Pollack Mihály, Ybl Miklós, nagyváradi székesegyház, protestáns templomépítészet

\section{TÉMAVÁLASZTÁS}

Doktori fokozatom megszerzése ${ }^{4}$ óta végzett kutatásaim tematikailag erősen kötődnek egyrészt a templomépítészet különböző résztémáihoz - ezen belül a 18-19.

${ }^{1}$ A BME-n 2016-2017-ben lefolytatott habilitációs eljárás tézisfüzete. A Budapesti Müszaki és Gazdaságtudományi Egyetem (BME) Építészmérnöki Tudományok Habilitációs Bizottsága és Doktori Tanácsa - müszaki tudományok tudományterületen, építészmérnöki tudományok tudományágban - 2016. június 10. és 2017. május 25. között bonyolította le a habilitációs eljárást. A nyilvános előadás A magyar katolikus székesegyházak épitészete a 18. században, majd a tudományos kollokvium Épületkutatás és épitészettörténet - néhány újkori és 19. századi épülettipus kutatásának módszertana és eredményei címen 2017. április 27-én volt. A BME Habilitációs Tanácsa 2017. május 25-én nyilvánította a jelöltet habilitált doktorrá.

${ }^{2}$ A történeti épületkutatás és építészettörténet legújabb kutatásmódszertani alapmüveiből fontos kiindulást jelent: Großmann 2010; Groat-Wang 2002; Schuller 2002; a magyar épületkutatás aktuális problémáinak vonatkozásában pedig Horler 1981; Marosi 1985; Feld 1999; Haris 2004; Mezős 2008; Mentényi 2009.

${ }^{3}$ A tézisekben a ,Bauforschung”-szemlélet (Bauforschung = épületkutatás) alatt a német terminológiát követve elsősorban az Armin von Gerkan, illetve Manfred Schuller által meghatározott módszertant értem, vö.: Schuller 2002.

${ }^{4}$ Krähling 1993. 
századi evangélikus, református és római katolikus emlékekhez -, illetve tágabb módszertani összefüggésben az alakhü felmérésen alapuló épületkutatáshoz. E kutatási módszer gyakorlata - több kisebb volumenü felmérés elvégzése után - egy nagyobb projekt keretében teljesedett ki: a magyar 18. századi kastélyépítészet kiemelkedő emlékének, a fertődi Esterházy-kastély marionettoperájának és narancsházának kutatásánál.

Számos kutatási projekttámogatás, illetve megbízás tette lehetővé, hogy kutatómunkámat folyamatosan végezhessem. Kandidátusi értekezésem eredményeire alapozva az Országos Tudományos Kutatási Alap öt ciklusban elnyert kutatási támogatásával sikerült a magyarországi evangélikus templomépítészet feldolgozását megalapozó adattárakat elkészíteni. Legjelentősebb kutatási megbízásomat a tanszéki keretben - Halmos Balázzsal és Fekete J. Csabával - elnyert fertődi marionettopera, víztorony és narancsház tudományos vizsgálata jelentette, melynek során - több szakterületet is felvonultató kutatócsoport közösen elvégzett munkájával - sikerült új eredményekkel jelentkeznünk. A kastélyegyüttes további részeinek kutatására is további tervek vannak elökészületben.

A katolikus plébániatemplomok és a 18. századi egyházi megújulás folyamatát az építészeti reprezentációval kiteljesítő székesegyházak témájában Nagy Gergely Domonkossal közösen elvégzett kutatásaink egyik kiemelkedő eredménye a nagyváradi székesegyház Hillebrandt-féle centrális tervének felkutatása és elemzése.

\section{A KUTATÁSOK CÉLJAI ÉS MÓDSZEREI}

\subsection{A KUTATÁSOK CÉLJAI}

A történeti épületekkel kapcsolatos kutatómunka céljai közt elsődleges az építéstörténet alapvető kérdéseinek megválaszolása, majd az emlék elemzésével és értelmezésével történeti, kulturális és építőmüvészeti kontextusba helyezése, a „narratíva" megtalálása. ${ }^{5}$ A célkitűzések más mélységű kutatást és eltérő módszertani megközelítést jelentettek a fertődi barokk épületegyüttesnél, a protestáns épülettípus topográfiaszintü feldolgozásánál, vagy éppen a jelentősebb egyedi emlékek forrásainak újbóli elemzésénél és értékelésénél.

\subsection{KUTATÁSMÓDSZERTAN}

\section{Bevezetés}

Az alkalmazott kutatásmódszertan alapelve, hogy a kutatás céltételezésénél az elméletileg megalapozott kérdésfelvetések, ezeken belül az alapkérdés határozza meg a módszert vagy módszereket, amellyel a kívánt eredmény elérhető. A módszer-

${ }^{5}$ Groat-Wang 2002. 138. 
tani újítás ugyanakkor - akár stratégiai, akár taktikai értelemben - önmagában is hozzájárulhat a tudomány fejlődéséhez, amelyet rendszerint új megközelítések és eredmények kísérnek. Az általam végzett kutatások esetében közös módszertani alapnak az épület fizikai létére összpontosító szemléletet tekintem, ${ }^{6}$ amelyben a történeti épület elsődleges forrásként ${ }^{7}$ - illetve archív forrásainak „referenciájaként” jelenik meg, és „olvasásának” filológiai alapját az alakhelyes felmérésen alapuló történeti szerkezetelemzés jelenti. Ennek kialakult európai gyakorlatára ${ }^{8}$ építve végeztem kutatómunkámat.

Az építészeti, építészettörténeti kutatás jellege módszertanát tekintve a par excellence művészettörténeti kutatást követi, de attól az építészet területét érintő lényegi pontokon némiképpen eltér, specializálódik annak általános módszertanához képest. A müvészettörténeti kutatás ikonográfiai, stílustörténeti, müvészetfilozófiai, ikonológiai kérdésfelvetéseinél nem a kutatás módszertani részére, hanem sokkal inkább az interpretációra, a narratívára összpontosít a kutató. A „mérvadó kutatói vélemény”-hez igazodó értelmezés kijelölheti a fó kutatási trendek követését, de magában hordozhatja a független körülmények és szempontrendszer mérlegeléséből adódó új megközelítések elmulasztását.

A korábbi évtizedek során kialakult hazai épületkutató gyakorlat ${ }^{9}$ elvi alapjait tekintve lényegében három fö szempont érvényesítésén alapul: az épület „megkutatásán", a források (írott dokumentumok, tervek, ábrázolások stb. - rendszerint közgyüjteményi leletek), továbbá a szakirodalom feltárásán és értékelésén. Az épület „megkutatása" a fizikai értelemben vett, roncsolásos jellegü falkutatást jelenti. Ez a kutatási szakasz - mivel itt a régészettel ellentétben nem a többé-kevésbé „semleges” talaj, hanem az önmagában értékes vakolat a közbülső réteg - a történeti állag jelentős és pótolhatatlan pusztulásával járhat. ${ }^{10} \mathrm{Nem}$ vitatható, hogy a roncsolásos kutatás szükségszerü lépése a folyamatnak. A régészet mintaadó módszerével ellentétben azonban - ahol a „,eltárás-dokumentálás-elbontás” lépéseinek betartása alapkövetelmény ${ }^{11}$ - a falkutatásnak nem létezik ehhez hasonló, leírt szigorú módszertana, amelyben a fázisonkénti dokumentálás - a rajzi feldolgozással együtt - az eredeti jelenséget kell, hogy helyettesítse a későbbi kutatás során. ${ }^{12}$ Meg kell ugyanakkor jegyezni, hogy a hazai épületkutatás gyakorlatáról - elsősorban a mủemlékvédelem kérdésköréhez kapcsolódóan - az elmúlt bő évtizedben több polemizáló cikk jelent meg, amelyben a dokumentálás igénye az értékleltárra összpontosítva egyre nagyobb teret kapott, az alakhü felmérés hazai tudományos módszertani szerepével kapcsolatban azonban sok kérdés maradt nyitott. ${ }^{13}$

${ }^{6}$ Horler 1981. 74; Marosi 1985. 5.

${ }^{7}$ Schuller 2002. 7.

${ }^{8}$ Morsbach 1990; Schuller 2002; Fiorani 2004; Boato-Pittaluga 2000; De Jonge-Van Balen 2002.

${ }^{9}$ Rendszerezett összefoglalása: Komárik 1994. A falkutatás gyakorlata tekintetében alapvető: Dávid 1978 - ebben a dokumentálás egyetlen egyszer, csupán a kutatás megkezdése előtti felmérésnél szerepel.

${ }^{10}$ Haris 2004. 300.

${ }^{11}$ László 2005. 106.

${ }^{12} \mathrm{~A}$ problémakör lényegét áttekinti: Tóth $1973.621 \mathrm{skk}$. és 628.

${ }^{13}$ Haris 2015; illetve Mentényi 2009. 150. 


\section{Az épitészettörténeti kutatás kérdésfelvetése}

Az épületek kutatásának egyik fő alapkérdése - mióta az építészettörténet mint tudományosan megalapozott diszciplína létezik - a müvészettörténet átfogóbb kutatói szemléletét követve a mü keletkezésére és azon belül kiemelten a datálásra, továbbá a megbízóra, a mủvészre (megvalósítóra), a használatra és a mủ jelentésére irányul, majd ennek alapján lehetséges a történeti és építészettörténeti összefüggések meghatározása. E gyakorlat módszertani eszköze a stílusfejlődés eszméje, amely egy történeti adatokból összeálló rendszer alappontjainak összefüggésében, rendszerint a korai, érett, a kései vagy meghaladott stílusformák egymást követő rendjére építve határozhatja meg a mü építészettörténeti helyét. ${ }^{14} \mathrm{~A}$ stíluskritikai összehasonlító elemzések nem biztosítanak mindig megbízható eredményt a datálás elvégzéséhez. ${ }^{15}$ Ennek oka lehet például a fő müvészeti tendenciáktól alig befolyásolt helyi fejlődés eltérö, ugyanakkor az épület vonatkozásában meghatározó karaktere.

A kutatott épület történetileg kialakult szerkezeti összefüggéseire összpontosító, az épület fizikai valóját elsődleges forrásként - korszak- és épülettípus lehatárolás nélkül - kutató, és alakhü felméréseken alapuló elemző szemlélet a „historische Bauforschung" (vagy történeti épületkutatás), ${ }^{16}$ amelynek része a természettudományos és egyéb módszerekkel végzett, sok esetben pontos datálást adó, történeti szerkezetet érintő diagnosztikai vizsgálat.

A kétféle megközelítés: az írott adatok hiányából adódó történeti szemléletủ stílusinterpretáció és a stíluskritikai rendszerbe sokszor nem illeszthető egzakt kormeghatározás - például a dendrokronológia eredménye - így ellentétbe kerülhet egymással. ${ }^{17} \mathrm{Az}$ alább kifejtendő tézisekben megfogalmazott kutatási kérdéseket a kétféle megközelítés együttes alkalmazásával lehetett nagyobb áttekintéssel megválaszolni; a célom az, hogy a módszertanban ezeket az eltérô szemléleti kiindulásokat integráljam.

\section{A történeti épületkutatás definíciója}

Történeti épületkutatás alatt azt a komplex kutatófolyamatot értem, amelynek célja, hogy az épületnek mint a kutatás tárgyának és elsődleges forrásának - a rá vonatkozó további források összességét is felhasználva - a történetileg kialakult formáját és szerkezeteit, azok keletkezésének körülményeit és összefüggéseit, valamint az idők folyamán bekövetkezett változásait rendszerezett formában, lehetőség szerint roncsolásmentesen vagy a legkisebb roncsolással feltárja. A történeti épületkutatás csapatmunka, amely az interdiszciplinaritás szellemében építészek, mérnökök, müvészettörténészek, régészek, restaurátorok közös munkájával, továbbá a tör-

\footnotetext{
${ }^{14}$ Großmann 2010; Marosi 1985. 5.

${ }^{15}$ Dávid 1978. 78.

${ }^{16}$ Schuller 1990; Schuller 2002.

${ }^{17}$ Schuller 2002. 28; Eißing 2005. 316 skk.
} 
téneti épület kutatását segítö, a leletek feltárásában és kiértékelésében jártas rokon szakterületek bevonásával valósul meg. ${ }^{18}$

A kutatás alapkérdését többféle módszertan szerint lehet megközelíteni. Az alapproblémát az írott történeti források elemzése alapján megválaszolva, tágabb értelemben a mü létrejöttének és történeti kontextusának elemzésére összpontosítva, a művészettörténet módszertana felől közelíthetjük meg a történeti épületkutatást.

A „Bauforschung” szemléletű épületkutatás tárgya a történeti épület a legteljesebb valójában, és e szemlélet szerint csak másodlagosak az egyéb történeti források többek közt az írott és képi ábrázolások -, valamint a tipológiai és stílustörténeti összehasonlító elemzések.

Az épületkutatás fogalma és a régészeti kutatás között nyilvánvalóan nagyon sok a rokonság. A „Bauforschung”-iskola kialakulásában a régészet módszereinek átvétele és álló épületre való alkalmazása játszott meghatározó szerepet. ${ }^{19} \mathrm{Az}$ épületkutatás és a régészet összefüggésében mérvadó Gert Thomas Mader módszertana az építéstörténeti-sztratigráfiai vizsgálatról, amelyet a régészetből származtat, és amely fontos része a „Bauforschung” szemléletnek. ${ }^{20}$ Az eljárás hasonló az itthoni falkutatáshoz, és a hazai falkutatási módszertan részletes elvi kidolgozása szempontjából - amelynek eddigi elmulasztása a magyar épületkutatás nagy hiányossága - mintaadó lehet. ${ }^{21} \mathrm{Az}$ építéstörténeti-sztratigráfiai vizsgálat nagyon lényeges része a helyszínen felvett és megfelelő részletezettségü felmérés, illetve a feltárt összefüggések egységes - és az épülettől független geometriai rendszerben történő - ábrázolása; anélkül ugyanis a falkutatás által nyert adatok nem értékelhetők megfelelően önmagukon túlmutató, a tudományosságot megalapozó rendszerezettségben.

\section{A történeti épületkutatás módszertani kérdései}

Az írott és rajzi források értelmezésének, valamint a szerkezetanalízisen alapuló alakhü felmérésnek a szerepe az épületkutatásban szorosan egymáshoz rendelt. A datálás módjai: az írott forrásokból nyert adatok, az épületen található feliratok, a természettudományos módszerek eredményei és a stíluskritikai alapon végzett datálás egyaránt csak az épületkutató által az épület teljes történeti szerkezetiségét feltáró - azaz a szerkezeti egymásra épülést bemutató - analízisével verifikálhatók. Ennek elsődleges eszköze pedig a rajzban, illetve vizuális formában a helyszíni megfigyelések gondos rögzítésével elkészített alakhü felmérés.

Mivel a történeti épületekről rendszerint nem áll rendelkezésre megfelelő részletezettségü, eredeti tervrajz, másrészt az nem az épület valós idejü állapotát mutatja, az épületkutatás gyakorlatának egyik módszertani alapeleme az épületfelmérés, amely a hitelesség, a pontosság, továbbá a gazdaságosság kritériumát is figyelembe

\footnotetext{
${ }^{18}$ Ilyen kutatást mutat be legújabban pl.: Daragó-Bakonyi 2015; Halmos-Marótzy 2015.

${ }^{19}$ Gerkan 1924; Schirmer 1995.

${ }^{20}$ Mader 1987; Mader 2005.

${ }^{21}$ Tóth 1973. 625; Mezős 2008. 380.
} 
véve a helyszínen készítendő. ${ }^{22}$ Az épületfelmérés hagyományos, mérési vázlattal (manuáléval) történő megvalósítása - amelynek feldolgozása nem a helyszínen készül - alapvetően jellemző a hazai gyakorlatban. ${ }^{23}$ Ennek tudományos módszertani szempontból a leggyengébb pontja, hogy a helyszíni vázlat feldolgozása, tervrajzzá érlelése a kutatott objektumtól távol, munkaasztal mellett történik, ezért a történeti épületről szerzett információk többségének rögzítése elmarad.

A történeti épületkutatás folyamatában a döntően az épület helyszínén végzett munkát megelőzi az objektum alapszintű megismerése, a rá vonatkozó publikációk, a szakirodalom és az archív írott, illetve képi források lényegi áttekintése. ${ }^{24} \mathrm{Az}$ épület bejárása és egy előzetes fotódokumentáció elkészítése után kb. 1:100-as léptékü vázlaton megtervezhető a felmérés tervezett munkaterülete, a helyiségek vagy épületrészek áttekintéshez szükséges számozása, a geodéziai alapfelmérés alappontjai, az illesztőpontok és a tengelyek rendszere. Az épületkutatás előkészítése jelentős tervezést is igényel, amelynek része az archívumokban végzendő kutatás - az írott, illetve képi források lehetőség szerint teljes felkutatása, majd elemzése. Az előkészítő munka része lehet - ha nem a mérés folyamán valósul meg - a geodéziai méróállomással végzendő mérés, amelynek vonalas alapformáit és vonatkoztatási pontjait rajzpapírra kinyomtatva könnyebben és hatékonyabban elvégezhető a helyszíni munka. ${ }^{25}$

Az építészeti fotogrammetria pontos dokumentációt eredményezhet, de nem tartalmazza azokat a nyomrögzítéseket, az épület testközelből elvégzett letapogatásának, értelmezésének és közvetlen rögzítésének rendszerét, amely a történeti épületkutatás egyik lényege. E módszerben egyre nagyobb szerepet kap a korszerü digitális mérési és dokumentálási technológia - a térszkennelés, tárgyszkennelés stb. -, amely a kutatás tárgyának virtuális térbeli leképzéseként is felfogható, és amely a sztratigráfia módszertanának megváltozásához vezet.

Az épületkutatás alakhűség szempontjai szerint készített rajzi dokumentációja a tudományosság alapvető kritériuma: a belső validálhatóság, megbízhatóság és objektivitás feltételeinek teljesítéséhez szükséges. ${ }^{26} \mathrm{Az}$ alakhü felméréssel lehetséges a történeti szerkezeti állagba fizikailag nagymértékben behatoló vizsgálatok - a régészet, valamint a restaurátori és szondázó falkutatás - fázisainak dokumentálása, a leletek elemzése, továbbá az eredmények közreadása az utólagos igazolhatóság, valamint az örökségvédelem szempontjainak is megfelelve.

A helyszínen felhordott dokumentáció, az épület „rajzi leírása” a történeti szerkezettan elmélyült ismeretén alapul. A legfontosabb elv, hogy a megfigyelés, mérés és rajzolás lehetőleg egy időben, egy komplex folyamat részeként a helyszínen történik - ez biztosítja a megfigyelés mélységét, ez sarkallja a kutatót a szerkezeti-történeti összefüggések kifürkészésére.

${ }^{22}$ Mader 1987; Cramer 1993.

${ }^{23}$ Hajnóczi 1956.

${ }^{24}$ Ennek a dokumentálása a „tudományos dokumentáció” mint alapvetỏ roncsolásmentes vizsgálati módszer - vö. Mezös 2008. 380.

${ }^{25}$ Schuller 2002. 11.

${ }^{26}$ Groat-Wang 2002. 36; Gerő 1958. 138; Tóth 1973. 628. 
A helyszíni felmérést kiegészítő adatrögzítési segédeszköz a történeti helyiségkönyv. ${ }^{27}$

Az épületkutatás módszertani eszköztárát a bölcsészet- és a természettudomány számos segédtudománya egészíti ki. Fontos módszertani részterület a lakóházkutatás, ${ }^{28}$ a restaurátori kutatás, a falsztratigráfia (falkutatás), a kronotipológia és nem utolsósorban a régészet.

A datálást segítő természettudományos módszerek közül - a vizsgálandó épületek korára és a pontosságra való tekintettel - a legfontosabb a dendrokronológia. A C14 (radiokarbon) módszer és a termolumineszcens (TL) kormeghatározás az épületkutatásban kevésbé elterjedt.

A műemléki helyreállítás komplex problémakörét érinti a későbbi helyreállítást tervező építész gyakorlatához igazodó alkalmazott épületkutatás, amely a helyreállítás tervének megalapozott előkészítését is célozza, és amelyben a korszerü épületdiagnosztikai módszerek elsődleges szerepet játszanak.

\subsection{AZ EREDMÉNYEK BEMUTATÁSÁNAK LEHETŐSÉGEI}

Az építéstörténeti kutatás alapvető kérdéseinek megválaszolása után különösen fontos a megfelelö értelmezés, kontextusba helyezés, az interpretáció és a „narratíva” megtalálása.

A téziseimben bemutatandó szempontok a történeti épületkutatás felvázolt módszertanát különböző mélységgel alkalmazó kutatások eredményeit értelmezik. A módszertani hangsúly kettős, egymáshoz szorosan kapcsolódó megközelítést mutat: egyrészt a „Bauforschung” szemléletü, objektumcentrikus, a feladathoz szükséges mélységü felmérésen alapuló helyszíni kutatást, másrészt az építészettörténeti kérdésfeltevésre nyitott írott és képi forráselemzést. Az elemzések a történeti-morfológiai kialakulás vizsgálatára irányulnak, amely adott épületre összpontosítva a hiteles elvi rekonstrukcióhoz és a megőrzéshez, tágabb építészeti emlékkör esetében tipológia felállításához, illetve az építészet kulturális beágyazottságára vonatkozó kérdéskör esetében az identitás, a hagyomány szerepének vizsgálatához vezetnek.

\section{TÉZISEK}

\subsection{TÉMAKÖR: TÖRTÉNETI ÉPÜLETKUTATÁS}

\section{Tézis:}

A fertődi Esterházy-kastély marionettoperájának barokk szinpadát egy interdiszciplináris kutatócsoport átfogó kutatómunkájának eredményeként, alakhü felmérésen alapuló épületkutatás alapján lehetett elméletileg rekonstruálni. A kutatás gazdag

${ }^{27}$ A helyiségkönyvről alapvető: Schmidt W 1989.

${ }^{28}$ Feld-Klein 2004. 
leletanyagának elemzö feldolgozása során az egykori marionettopera barokk színpadának értelmezését és elméleti rekonstrukcióját végeztem el. A történeti források, mindenekelött a levéltári anyagban található „Wintertheater” tervének értelmezése, továbbá a munka különbözö fázisaiban egységesen 1:20-as léptékben elvégzett helyszini felmérések, adatgyujjtések és megfigyelések, majd erre alapozottan a régész társkutatók eredményeihez illeszkedö, azokat integráló egységes és rendszerezett elemzés és értékelés nagyságrendekkel bövitette a különleges jelentöséggel biró épülettipusról alkotott képünket, ami a jövöben az operaszínpad rekonstrukciójához vezethet.

A fertődi (a korabeli névhasználat szerint eszterházai) Esterházy-kastély marionettoperájának és narancsházának együttese kiemelkedő helyet foglal el Európa barokk kastélyépítészetében. A marionettszínház barokk színpadgépezetével, Joseph Haydn és kortársainak báboperáit bemutató jelentős repertoárjával az európai zenetörténet, kastélykultúra és színházépítészet különleges emléke.

A marionettopera és narancsház, valamint a köztük álló víztorony épületkutatása tanszéki kutatócsoport munkájával - Halmos Balázs és Fekete J. Csaba folyamatos részvételével -, több szakági kutató intézmények közötti kooperációjával - többek közt Koppány András régész, a régészeti kutatás helyszíni irányítójának bevonásával - interdiszciplináris módszertannal valósult meg, amely az Európában egyedülálló és kiemelkedő jelentőségủ épületegyüttes történetének és eredeti kialakításának mélyebb megismerését eredményezte.

A 2004 és 2013 között elvégzett folyamatos kutatómunka során az épületkutatás interdiszciplináris módszerei mentén lehetőség nyílt a régészet, valamint a roncsolás minimalizálására törekvő „Bauforschung” szemléletű kutatás eszközeit és módszereit ötvözve az épületegyüttes olyan mélységü megismerésére, amely lehetővé tette az épülettömeg és a belső térszervezés elméleti rekonstrukcióját, egyúttal kijelölte a kutatás további irányait is.

A történeti szerkezetekre koncentráló interdiszciplináris elemzés és kiértékelés legfontosabb irányait a fellelhető írott és képi források tükrében az épülettípus, az alaprajzi struktúra, rendeltetésnek megfelelö müködés, a falszerkezetek, a térlefedés, a fedélszékek, a homlokzattagolás, a belsőépítészeti kialakítás, a díszítések, továbbá a barokk színpadtechnika és a történeti épületgépészeti megoldás (víztorony, légfütés) jelentették (1. ábra).

Az általam elvégzett elemzés legfontosabb eredményei: az Eszterházára vonatkozó levéltári anyagban fellelhető „Wintertheater” tervének a marionettszínházzal történő azonosítása; és a színház osztófalainak, belső párkányzatának és - helyszíni leletek, analógiák, valamint történeti szerkezettani minták alapján - a De L'Ormeféle faboltozattal megoldott térlefedés meghatározása. A barokk színpadtér geometriai rekonstrukcióját a régészeti feltárás alapján - ezen belül különösen a proszcéniumnyílás és a szintviszonyok feltárt eredményeire alapozva - a több kutatási fázisban elvégzett alakhü felmérések történeti szerkezetcentrikus összegzése és elemzése, továbbá a levéltárban talált színpadábrázolás értelmezése, valamint a Pozzo-féle színpadperspektíva-ábrázolás elvének alkalmazása tette lehetővé. 

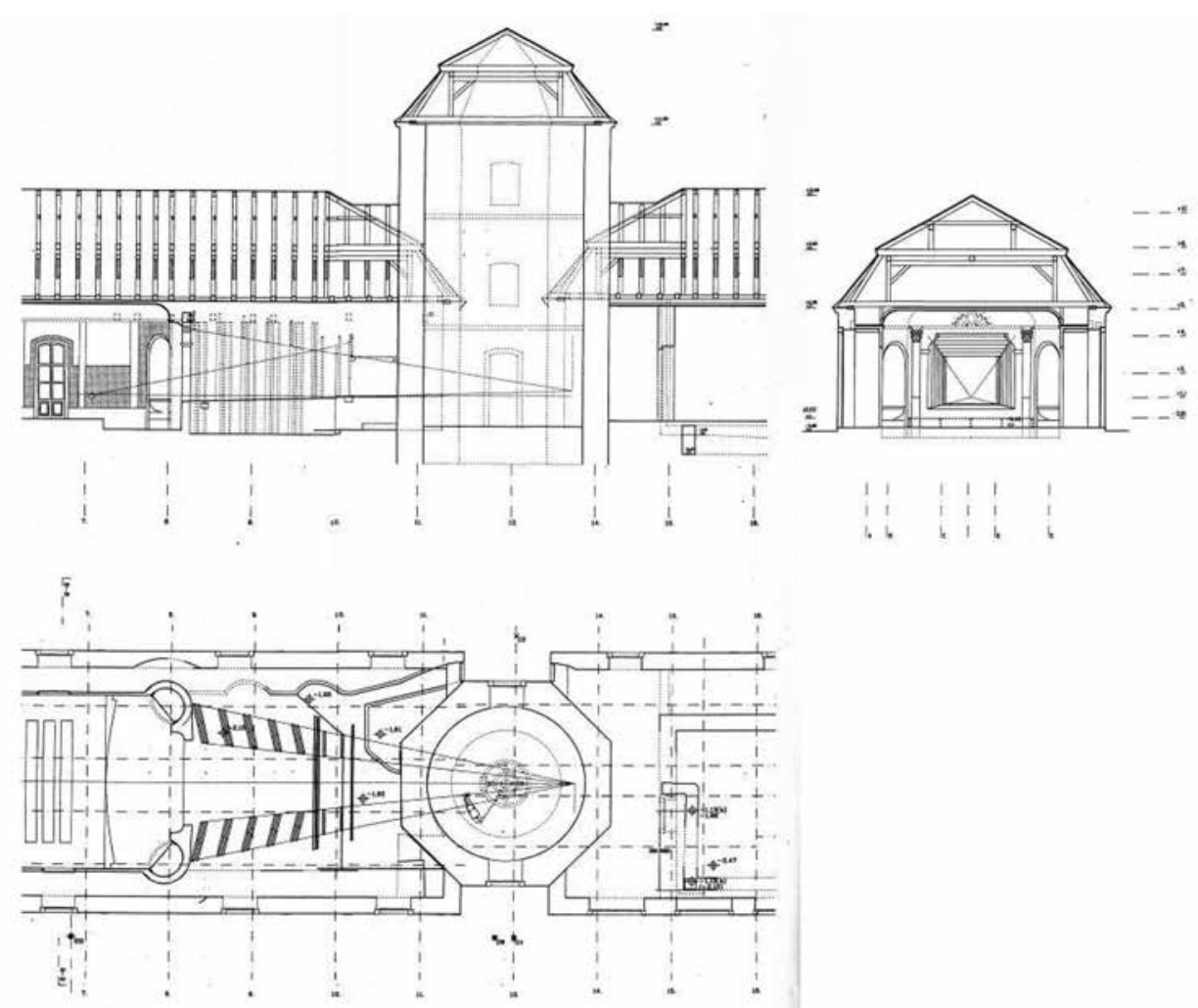

1. ábra. A fertődi Esterházy-kastély marionettopera színpadának elvi rekonstrukciós vázlata (Krähling et al. 2013. 90. Fig.9.)

Az épületegyüttes külső és belső megjelenésének, továbbá szerkezeti kialakításának visszaállításhoz ${ }^{29}$ a Bauforschung szemléletü épületkutatás eredményei alapvetően hozzájárultak. Az egykori marionettopera barokk színpadának értelmezése és perspektívaszerkesztésének meghatározása lehetőséget nyújt a barokk színpad jövőbeni, további restaurátori kutatásokkal megalapozott rekonstrukciójához.

\section{Kapcsolódó publikációk}

Krähling-Halmos-Fekete 2006

Krähling et al. 2013

${ }^{29}$ Generál tervező: M Építész Iroda Kft. Építészek: Molnár Csaba DLA, Szentkuti Viktor, Halmai Dénes; építészettörténeti konzulensek: Dr. Krähling János, Dr. Halmos Balázs, Dr. Fekete J. Csaba; régész kutatók: Koppány András, Kupovics Renáta, Thury László; tartószerkezet: Armuth Miklós; akusztika: Reis Frigyes, Nagy Attila Balázs; épületszerkezeti szaktervező: Dr. Kakasy László, Dobszay Gergely; épületgépészet: Lovas Albert; elektromos tervező: Beharka Zsolt, Zentai Csaba. Építtető: Müemlékek Nemzeti Gondnoksága; http:// meonline.hu/archivum/barokk-mese/ (Utolsó megtekintés: 2016. 05. 10.) 


\subsection{TÉMAKÖR: TIPOLÓGIAI RENDSZEREZÉS}

\section{Tézis:}

A hazai evangélikus templomok tipológiai vázlatát egy nagyobb épitészettörténeti összefüggésrendszerben lehet áttekinteni, amelynek kronológiai határait jelentös egyháztörténeti események határozzák meg. Az országban található emlékek teljes felmérése és kutatása alapján felállított tipológiai rendszert az ismert alföldi, észak-magyarországi és nyugat-magyarországi épülettípusok mellett új csoportként a Nógrád és Veszprém megyére, valamint a Dél-Dunántúlra jellemzö regionális evangélikus templomtípussal egészitettem ki.

A tipológiai rendszert meghatározó korszakolás történelmi választóvonalait a reformált egyházak 16. századi kialakulása után az 1681. évi vallásügyi törvények, II. József 1781. évi türelmi rendelete, az 1848-1849. évi forradalom és szabadságharc, valamint az első és a második világháború, majd a rendszerváltozás jelöli ki. Az építészettörténetben összefoglalóan protestáns templomtípusként említett jelenség a stíluskorszakok, a történeti kontextus, a vallásügyi törvénykezés, az építtetői szándék, a tér- és tömegalakítás elemzése, a liturgikus térhasználat és berendezés, továbbá a közösségi funkció szempontjai szerint fö- és altípusokba csoportosítható (2. ábra).

Az elvégzett kutatás a felvázolt kronológia 19. század első évtizedéig tartó első három szakaszára összpontosít. A kutatás módszertani szempontból egyrészt az archívumok forrásainak és a szakirodalomnak az áttekintésén, másrészt a különböző

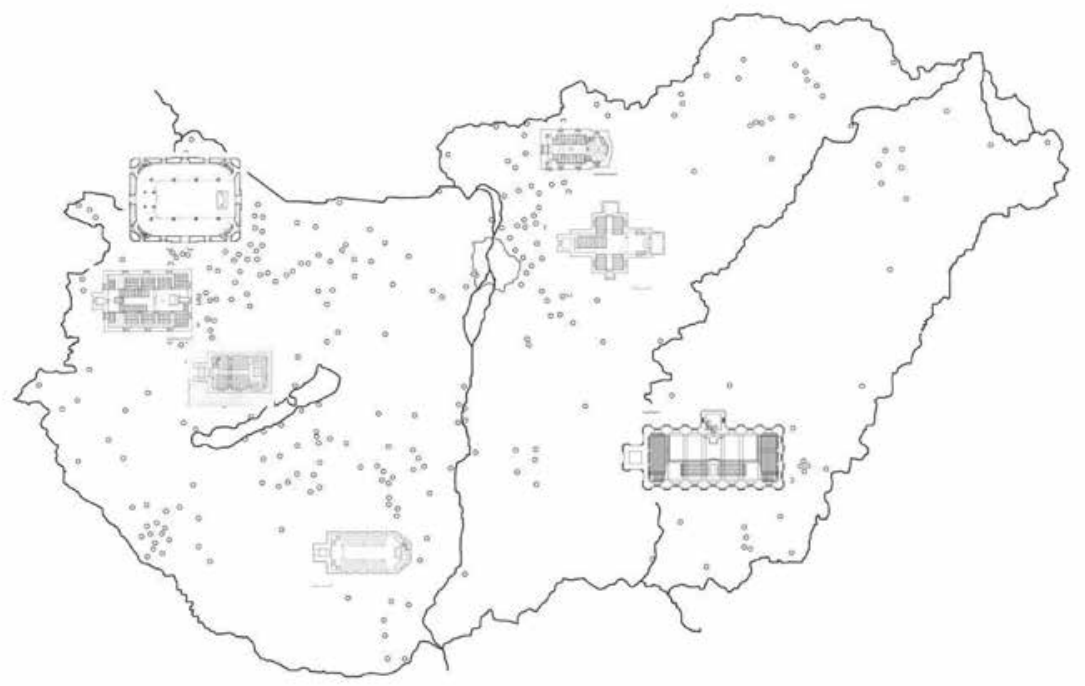

2. ábra. A mai Magyarország felmért evangélikus templomainak tipológiai eloszlása (Krähling 2015. 141. Fig. 23.) 
részletességgel - leginkább manuáléval - készített felméréseken alapult. A típusok meghatározása az eddigi protestáns templomépítészetre vonatkozó rendszerezéseket - elsősorban Bibó István és Winkler Gábor kutatásait ${ }^{30}$ - a magyarországi építészettörténet európai kapcsolatai, a hazai építészeti folyamatok és a regionális jellegzetességek meghatározása szempontjából is új csoportokkal bővíti: az alföldi, észak-magyarországi és nyugat-magyarországi típusok mellett új csoportként a nógrádi, valamint a Veszprém megyére és a Dél-Dunántúlra jellemző regionális evangélikus templomtípussal. Ezek a protestáns templomformák különösen a türelmi rendelet korának építészeti képét gazdagítják.

\section{Kapcsolódó publikációk}

Krähling 2004

Krähling 2015

\subsection{TÉMAKÖR: ÉPÍTÉSZET ÉS IDENTITÁS}

\section{Tézis:}

A hazai protestáns templomépítészet átfogó kutatása során összegyüjtött, építészettörténeti szempontból sokrétü topográfiai anyag elemzésének egy lehetséges szempontja az építészet és identitás viszonylatának értelmezése. A téma vizsgálatát Jan Assmann-nak és iskolájának a kulturális emlékezet és liturgikus tér viszonylatát értelmező alapvető kultúraelméleti megközelítése alapozza meg. ${ }^{31}$ A magyarországi evangélikus emlékanyag kutatása során a templomok téralakitását és belsö formálását, valamint a használók vallási és kisebbségi identitásrétegeit párhuzamosan vizsgálva a típusok identitásmegerösitö szerepét fedezhetjük fel. Veszprém megye magyar, Dél-Dunántúl német, valamint a Pest, Nógrád megyékben, továbbá az ország keleti részén található szlovák gyülekezetek templomépitészetében a téralakitás, térhasználat jellemző identitáshordozó típusait határozhatjuk meg.

Az identitás templomépítészeti kifejeződését a kulturális emlékezet többféle formája határozhatja meg, amelyben nagy szerepet kap a tipikus középkori falusi templomforma (torony - egy hosszanti hajó - diadalív - keskenyebb szentély) mint viszonyítási pont, továbbá a liturgia alakulása. A típusokra jellemző egyedi formajegyek a népcsoportok saját kulturális emlékezetéből fakadó vallási identitásának kifejezői. A templomtér önmagában nem alkalmas arra, hogy adekvát módon fixálja és materializálja az ünneplő közösség kulturális identitását, azonban mind a térstruktúra és a liturgikus térelrendezés, mind pedig a berendezés vonatkozásában fontos identitáshordozó vonásokat mutat (3. ábra).

\footnotetext{
${ }^{30}$ Bibó 1984-1985; Bibó 2013; Winkler 1992.

${ }^{31}$ Assmann 2000; Brüske 2001.
} 

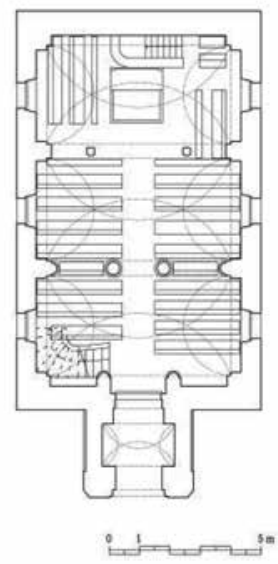
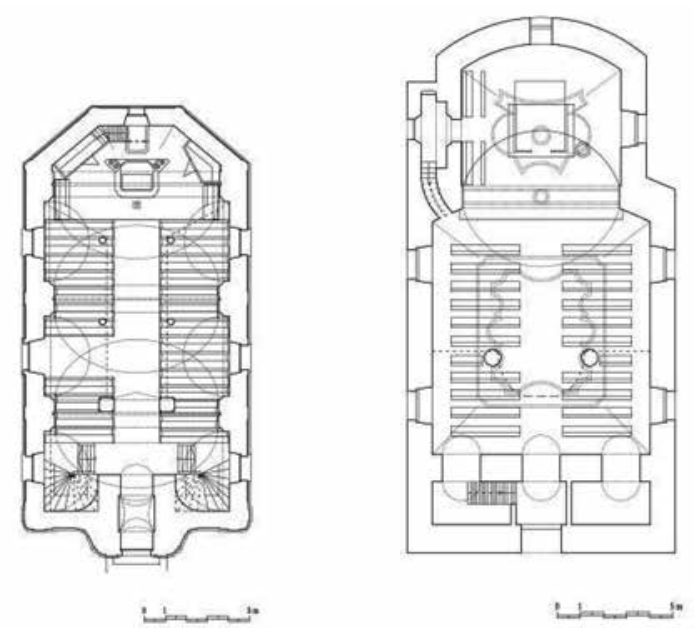

3. ábra. Jellemző típusok: Veszprém megyei (Felsődörgicse, ev. templom, magyar), dél-dunántúli (Kismányok, ev. templom, német) és Nógrád megyei (Bánk, ev. templom, szlovák) példával

Veszprém megye evangélikus gyülekezeteire jellemző a magyar lakosság folyamatos jelenléte, amely különösen jelentős annak tükrében, hogy itt található a mai határainkra vonatkoztatva a legtöbb középkori eredetü evangélikus templom. ${ }^{32}$

A templomépítészeti kérdéseket vizsgálva először az alaprajzi formáról kell szót ejteni. A templomok meghatározó többsége önálló szentélybővület nélküli, egyenes záródású teremtér. Ez a Nyugat-Magyarországra jellemző egyenes záródású (karzatokkal körülvett) teremtér megoldásokkal rokon, és az artikuláris templomokra is jellemző. Tágabb építészettörténeti összefüggésben a hosszanti teremtér NyugatMagyarország legjelentősebb 17. századi mintaadó evangélikus templomára, az 1638-ban épült (1672-ig evangélikus) pozsonyira vezethető vissza. ${ }^{33}$ A karzatok típusalkotó többsége jellemzően a templom keskeny végfala felöl legfeljebb a középtérig elörenyúló, U alakú elrendezést követ, amely éppen az átmenetet jelenti a középkorból örökölt hátsó karzat és a Nyugat-Magyarországra jellemző, a három oldalon teljesen körbefutó elrendezés között.

A Veszprém megyére jellemző típus legfontosabb liturgikus berendezése a szószékoltár, az evangélikus felekezeti identitás legfontosabb eleme, amely a 18. század végi templomoknál egy egyenesen záródó teremtér végfala előtt, a karzatokkal nem megosztott teremtérrészben áll. Jellemző térlefedés a hevederes cseh- vagy csehsüveg boltozatsor.

A Veszprém megyei típus a középkori falusi templom hagyományát és a NyugatMagyarországra jellemzö hossznégyszög formát sajátosan ötvözi. Az egyszerü alaprajzi forma használata, a redukált karzatrendszer és az európai evangélikusság litur-

\footnotetext{
${ }^{32}$ Bakonyszentlászló, Dabrony, Kővágóörs, Lovászpatona, Mencshely.

${ }^{33}$ Krähling 2009. 192-193.
} 

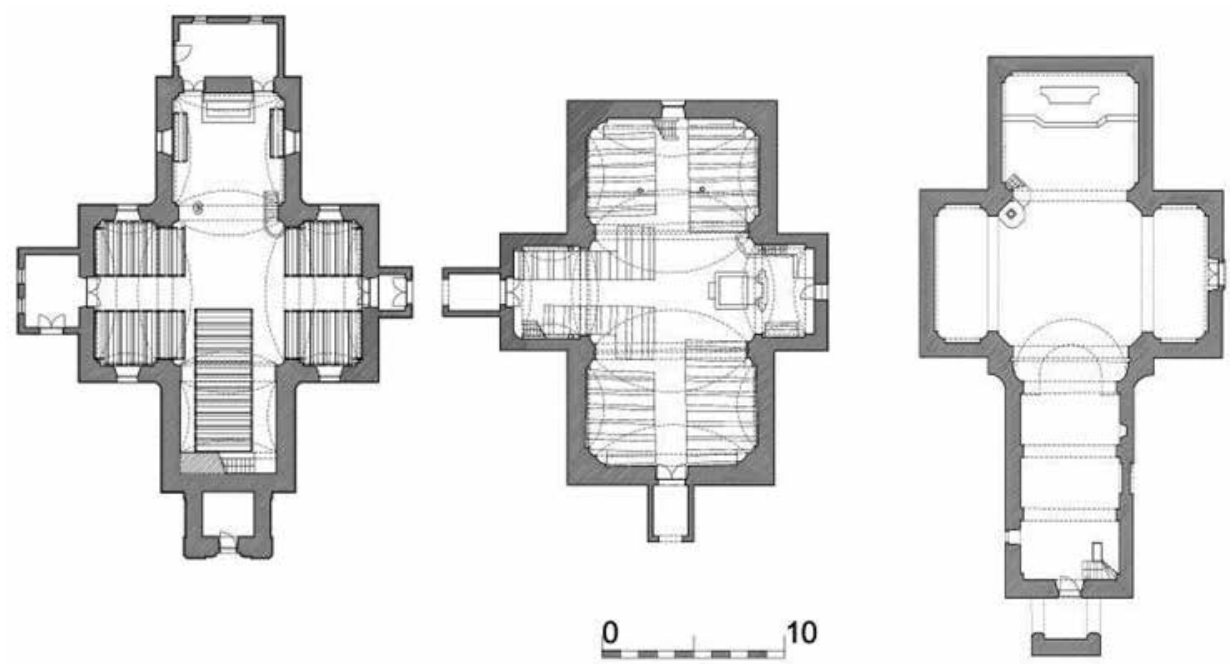

4. ábra. Jellemző centrális típusok (Maglód, Domony, Cinkota - szlovák gyülekezetek)

gikus térhasználatára jellemző szószékoltár az itt élő evangélikus magyarság építészeti identitáshordozója.

A dél-dunántúli németség templomaira jellemző az uralkodó iránti hódolat markáns megjelenítése: II. József (és I. Ferenc király, másképpen II. Ferenc császár) képének kiemelt - az oltárhoz közel, de attól határozottan elválasztott - helyen történő ábrázolása, amely a vallásszabadságot biztosító és a templomépítést lehetővé tevő felvilágosult uralkodónak állít emléket. ${ }^{34}$ Ez a jelenség a 18. század elejétől betelepült németség identitásának jellemző kifejeződése, amely az új hazára lelt alattvalók törvénykövetésére és engedelmességére is utal. Az általuk használt térforma döntően a téregységesítésre törekvő német protestáns hagyomány és az újratelepített falvak adaptált kamarai típustervei által meghatározott templomforma összhatásaként értékelhető: a diadalív nélküli poligonális végződés, a hosszanti elrendezés, az oldalhomlokzat kettős ablaksora és a szentélybe állított szószékoltárt hangsúlyozó karzatrendszer önálló dél-dunántúli evangélikus templomtípust határoz $\operatorname{meg}^{35}$ (4. ábra).

A szlovák gyülekezetek sajátos vallási identitását meghatározza a reformáció kezdeti időszakára jellemző, alig módosított, hagyományos (katolikus) liturgia elemeinek használata, ${ }^{36}$ amely építészetileg a katolikus templomforma megtartásával, a diadalívvel leválasztott szentélytér hagyományos formájával párosul; ez a forma a Nógrád megyében található jelentős számú szlovák gyülekezet templomait jellemzi. Ezzel összhangban, a német - és európai - protestáns téregységesítő tendenciáktól

${ }^{34}$ Krähling 2013. 182.

${ }^{35}$ Krähling 2013. 177 skk.

${ }^{36}$ Raffay 1944. 476. 
való elhatárolódást jelzi a szószékoltár mellőzése, a hagyományt követő retablóoltár és az elválasztott szószék alkalmazása. Hasonlóképpen a szlovákságra - Pest megye és az ország keleti részén sporadikusan található szlovák gyülekezetekre - jellemző tradíció a faépítészet hagyományával összhangban lévő, Felvidék és Szilézia protestáns templomépítészetével rokon centrális térképzés. ${ }^{37}$

\section{Kapcsolódó publikációk}

Krähling-Nagy 2011

Krähling 2013

\subsection{TÉMAKÖR: ÚJÍTÁS ÉS HAGYOMÁNY}

\section{Tézis:}

Az építészeti tervezés egyik alapvető dualitása a hagyományőrző építtetői akarat és a megtervezendő épület racionalitása, illetve a tervezői újítás és egyéni művészi kifejezés szándéka között húzódó feszültség, amely meghatározza az építészeti alkotás alakulását. Ennek az újító szándéknak fontos vonulata a szerkezetiség, amely megoldatlansága esetén - adott esetben mintaadó építészeti alkotások meghiúsulásához vezet. Történeti szerkezettani elemzés alapján - a fellelhetö irott és rajzi források, valamint az álló épület szerkezeteinek áttekintésével - bizonyitható, hogy a nagyváradi barokk székesegyházat eredetileg Franz Anton Hillebrandt tervezte. Nagyvonalú, hatalmas centrális ovális kupolával tervezett épülete szerkezetileg nem volt megvalósitható, ezért Giovanni Battista Ricca szerzőségével új terv készült, amely a ma is álló székesegyház felépitését eredményezte.

Pollack Mihály Deák téri evangélikus temploma - Pest elsö jelentös klasszicista épülete - Leonhard Christoph Sturm egyik mintatervét követi, lényegre összpontositó épitészeti térformálása, következetesen klasszicizáló tagozatrendszere pedig Palladio velencei templomainak ismeretére is utal. A templom eredetileg (1799-ben) tervezett fa dongaboltozatát - többek között a mintaterv szerkezeti hiányossága miatt-késöbb (1875-ben) át kellett épiteni.

Franz Anton Hillebrandt és Pollack Mihály egy-egy jelentős művének, a nagyváradi római katolikus székesegyháznak, valamint a pesti Deák téri templomnak kutatása, történtetiforrás-elemzése és építészeti értékelése kapcsán bemutatható a 18. század második felében kibontakozó, a klasszicizmus iránti megújulásra nyitott tervezői hozzáállás, illetve az építtetői hagyománytisztelet közt feszülő építészeti alkotófolyamat, amelynek ,eredménye” mindkét esetben a magyar építészettörténet egy-egy kiemelkedő alkotása (5. ábra).

\footnotetext{
${ }^{37}$ Krähling-Nagy 2011.
} 


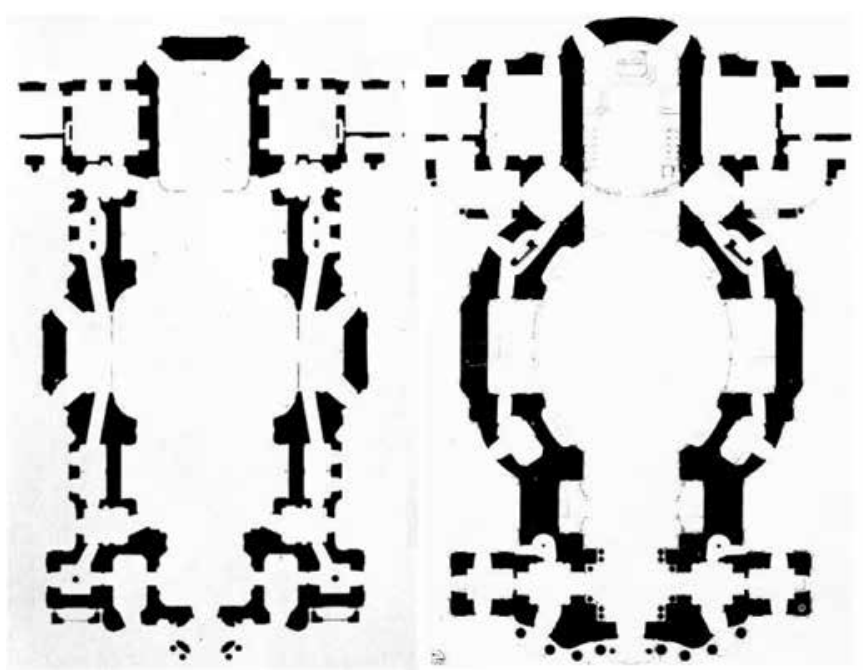

5. ábra. A nagyváradi római katolikus püspöki székesegyház Hillebrandt-féle első és második tervvariánsa - alaprajzok, 1750 (Krähling-Nagy 2013. 85. 3. kép)

Franz Anton Hillebrandt tervezői közremüködése a nagyváradi székesegyház barokk kori újjáépítésében építészettörténetünk régóta megválaszolatlan kérdése volt. A tervező személyének kérdésével Bíró József, majd Kelényi György alapvető monográfiái foglalkoztak. ${ }^{38} \mathrm{~A}$ kérdés megválaszolásának módszertani megközelítésében - egy véletlenül fellelt korábbi tervvázlat térkoncepciójára alapozva - a Hillebrandt-féle tervekre vonatkozó 1750-51-es leírások forrásértelmezésére, továbbá az eddig nem attribuált tervek átnézésére, és az írott formában fennmaradt szakvélemény épületre vonatkoztatott történeti szerkezeti elemzésére koncentráltunk. A nagyváradi székesegyház forrásainak történeti-szerkezettani szempontú áttekintése és elemzése, valamint további tervdokumentumok felkutatása alapján vált bizonyíthatóvá a korábbi sejtés, hogy a ma is álló templomot Ricca tervezte. Hillebrandt eredetileg tervezett ovális kupolás centrális székesegyházának megvalósulását alapvetően szerkezeti megoldhatatlansága hiúsította meg (6. ábra).

Pollack Mihály Deák téri temploma - elődje, Krausz János meglehetősen konzervatív szemléletü tervével szemben - erősen redukált, téglalap alaprajzú, osztatlan dongaboltozattal fedett terével és szigorú portikuszával - Zádor Anna alapos elemzése és értékelése szerint ${ }^{39}$ - a klasszicizáló késő barokkal szakító új stílus kiemelkedő emléke. A Deák téri evangélikus templom Leonhard Christoph Sturmnak a protestáns templomépítészet barokk teoretikusának egyik Nicolaus Goldmannra visszavezethető mintatervéből indul $\mathrm{ki}^{40}{ }^{40} \mathrm{~A}$ jelentősen egyszerüsített, a lényegre

${ }^{38}$ Bíró 1932; Kelényi 1976.

${ }^{39}$ Zádor 1960. 84 skk.

${ }^{40}$ Sturm 1718. Tab. A. 

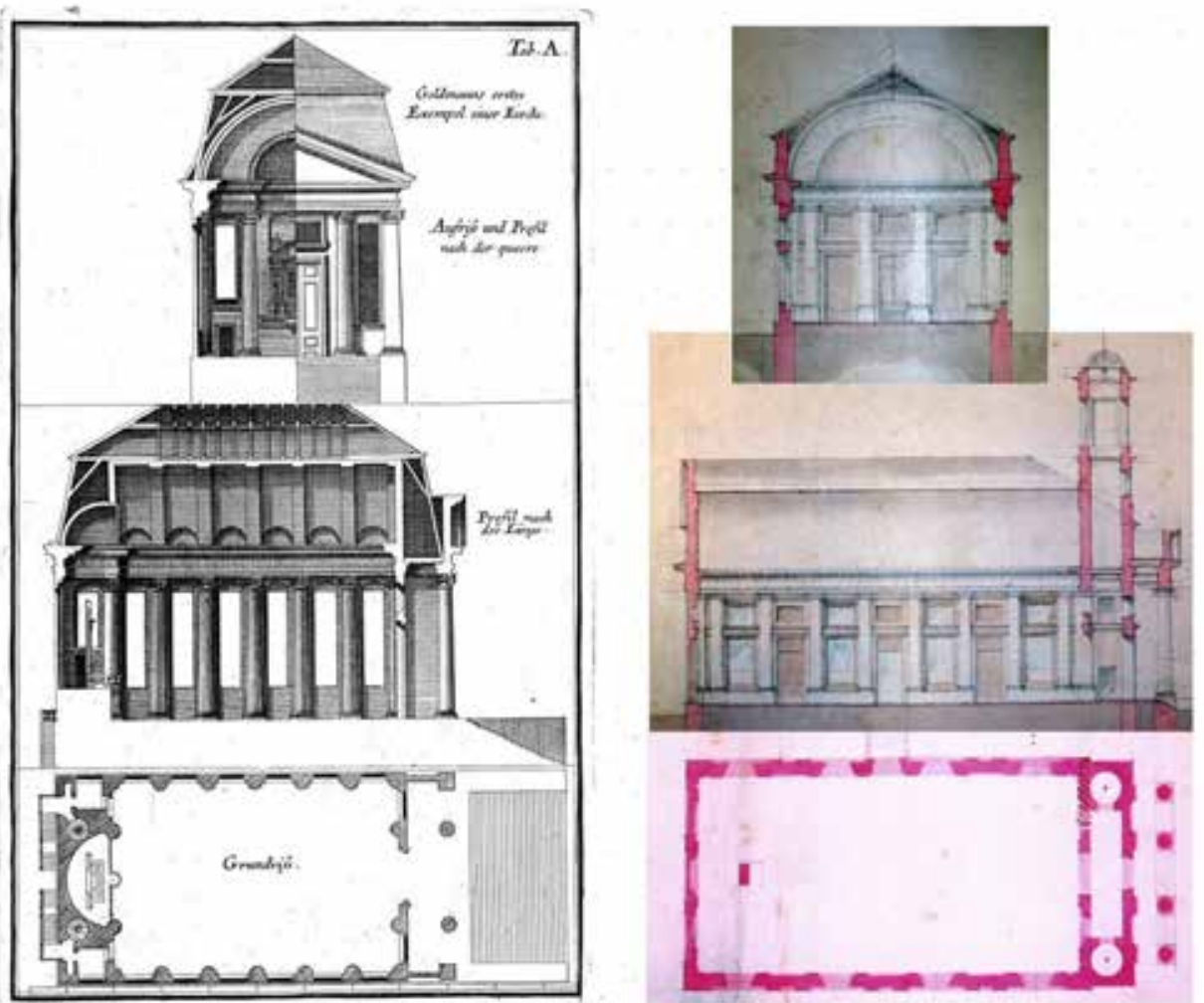

6. ábra. Leonhard Christoph Sturm (Nicolaus Goldmann) mintaterve (1718) és a Deák téri evangélikus templom terve (Pollack M. 1799)

összpontosító alaprajzú tér építészeti megformálása, következetesen klasszicizáló tagozatrendszere viszont Palladio velencei templomainak ismeretére is utal. A Sturmféle mintaterv fa dongaboltozata ötvözödik a palladiánus hagyománnyal, a vicenzai Basilica tetö- és térlefedés formájának megidézésével. A többféle hagyományt követő templom a palladianizmus építészeti nyelvén rendkívül választékosan megfogalmazott alkotás, Pollack gazdag életmüvének első remeke, a klasszicizmus elveinek következetes alkalmazására tett állásfoglalása, Pest első jelentős klasszicista épülete. A templom eredetileg (1799-ben) tervezett fa dongaboltozatát - a minta szerkezeti hiányossága miatt - később, 1875-ben koporsófödémre kellett átalakítani, amely a vicenzai Basilica terét idéző belsőt jelentősen megváltoztatta. ${ }^{41}$

A nagyváradi székesegyház és a pesti Deák téri templom tervezésének koncepcióit összehasonlítva, a hagyomány és újítás szempontjai szerint elemezve és a közös tanulságot keresve, az építészet egyik fontos tartalmi alkotójának, a szerkezetiségnek

\footnotetext{
${ }^{41}$ Krähling 2009. 191.
} 
kutatásmódszertani fontosságát kell kiemelnünk. A történeti szerkezeti elemzés ${ }^{42}$ az épületkutatás egyik meghatározó szemléleti alapja, az építészet tudományának fontos részterülete, amelynek az újítás és hagyomány viszonylatában is meghatározó szerepe van.

\section{Kapcsolódó publikációk}

Krähling-Nagy 2013

Krähling 2009

\subsection{TÉMAKÖR: ÉPÍTÉSZETI LELEMÉNY ÉS MINTAKÖVETÉS}

\section{Tézis:}

Ybl kecskeméti evangélikus temploma a magyarországi romantika templomépitészetének jelentös alkotása, amely az épitészeti lelemény és mintakövetés 19. századi problematikájának - a tervezési feladathoz választandó stílusforma és szerkezet illesztésének egyedi megoldása, a Schinkel-iskola egyik publikált templommintatervének adaptálása.

A templom centrális volta egyrészt $Y b 1$ fóti együttesének tervvariánsain, másrészt a pesti szlovák evangélikus templommal rokon koncepcióján alapul. A templom térstruktúrájának elemzése során nyilvánvalóvá vált, hogy a terv egy korabeli porosz minta, Karl August Soller 1845-ben publikált ${ }^{43}$ adaptációjával jött létre.

A mintakövetés állandó alapkérdése az építész tervezői koncepciójának és hozzáállásának, amely szembeállítható az építészi leleménnyel, de mindkét megközelítésmódban tetten érhető a megújítás szándéka. Az építészeti lelemény és a mintakövetés kettőssége egyfelől az alkotó személyisége és egyéni világa, valamint az építészeti kultúra társadalmi, közösségi igényeinek szintjén, ${ }^{44}$ másrészt a helyes szerkezeti kialakításra irányuló törekvésben jeleníti meg ezt a szándékot. ${ }^{45} \mathrm{Az}$ építészek értékrendjében hagyományosan elfogadott, hogy az alkotó módon felhasznált minta vagy előkép eredeti, új alkotást eredményez. A mintakönyvek a reneszánsz kora óta egyre jelentősebb szerepet játszottak az építészeti tervezésben, amely a 19. századtól teljesedett ki, és amely folyamat a század végére - elsősorban a második ipari forradalom hatására - az építészet szellemi és technológiai megújulását jelentette.

Ybl templomát abban az összefüggésben kell értékelnünk, amely egy építészeti korszakokon átívelő, az európai protestáns templomépítészet szellemi csatornáin kibontakozó folyamat része, amelyben a centrális tér egyik alapformája a 19. századi

\footnotetext{
${ }^{42}$ Schuller 2002.

${ }^{43}$ A Soller-féle terv adatai: (Johann Karl) August Soller: „Evangelische Kirche mit 1000 Sitzplätzen.” In: Entwürfe 1845. Fellelhető: Technische Universität Berlin Architekturmuseum in der Universitätsbibliothek Inv. Nr. B 1287,69: Perspektivische Ansicht, Choransicht, Querschnitt, Grundriss Oberbau, Unterkirche. http://architekturmuseum.ub.tu-berlin.de/index.php?set=1\&p=79\&DatEnten=175582 (Utolsó megtekintés: 2016. 05. 10.)

${ }^{44}$ Marótzy 2005. 28.

${ }^{45}$ Redtenbacher 1879. 539.
} 

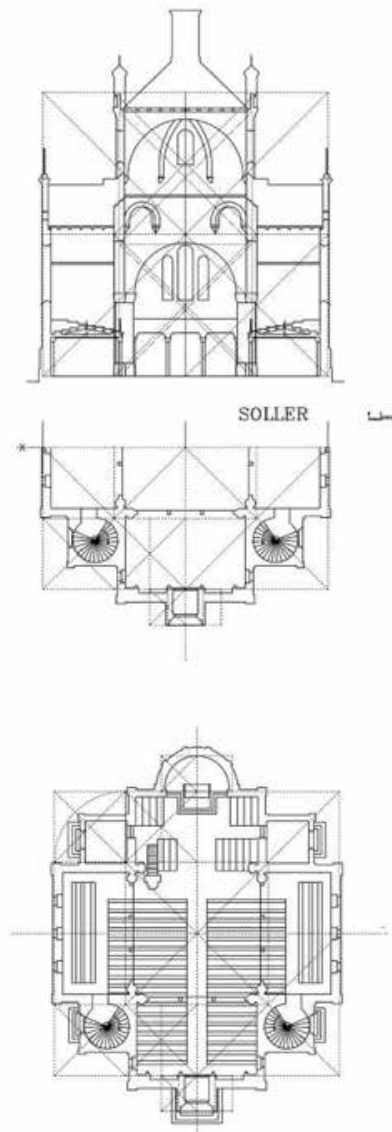

SOLLER

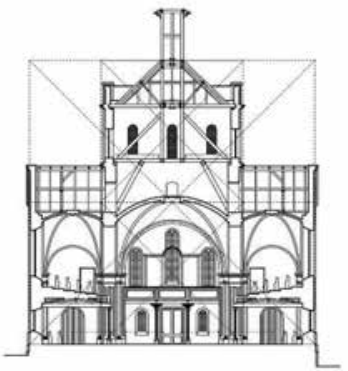

YBL.

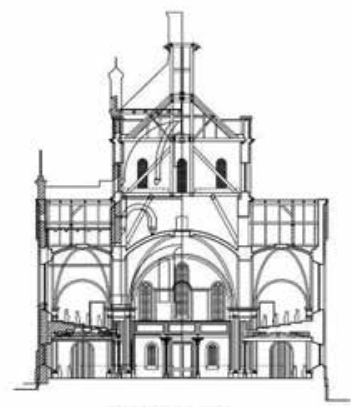

SOLIER + YBL

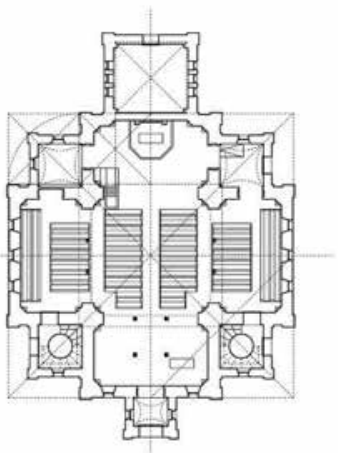

YBL

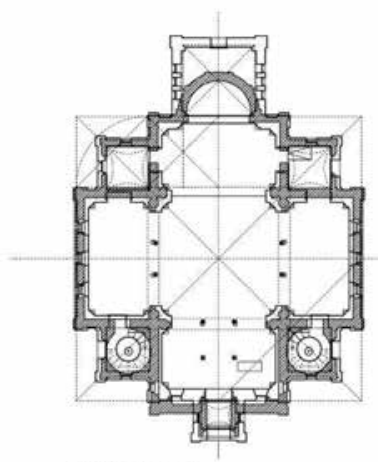

SOLER + YBL

7. ábra. K. A. Soller (1845) és Ybl Miklós tervének összehasonlító elemzése (Krähling 2014. 175. Abb. 8, 9.)

német Schinkel-iskola mintaterve ${ }^{46}$ révén reinkarnálódik, és közvetítésével jut el a kései középkorból a 20. századba. A kecskeméti evangélikus templom egyrészt a hazai romantika közép-európai beágyazottságának fontos megnyilvánulása, másrészt a hazai centrális templomépítészet egyik eredeti emléke, amely például Sándy Gyula diósgyőr-vasgyári templomához mintaként is szolgált (7. ábra).

\section{Kapcsolódó publikációk}

Krähling 2007

Krähling 2014

${ }^{46}$ (Johann Karl) August Soller: „Evangelische Kirche mit 1000 Sitzplätzen.” In: Entwürfe 1845. 


\section{AZ EREDMÉNYEK HASZNOSÍTÁSÁNAK LEHETŐSÉGEI}

A tézisekben bemutatott módszertan összefoglalásának „hasznosítása” lehet az a folyamat, amelynek során az újabb kérdésfelvetésekre folyamatosan továbbfejlesztett módszertannal igyekszik válaszolni a kutató. A gazdag szakirodalom áttekintése is arról tanúskodik, hogy módszertani szempontok szerint eltérő kiindulás jellemzi a különböző épületkutató irányzatokat, illetve azon belül a szakágakat, amelyek hatékonyságát hitünk szerint csak a csapatmunka növelheti. Az alapelvek összefoglalása és kritikus újragondolása - bármilyen szakterület felöl közelítünk - ennek az interdiszciplináris módszertani fejlesztésnek az alapja lehet.

Amint ezt a bevezetőben is hangsúlyoztuk, a bemutatott módszertan és a kutatási feladatok alapvetően csapatmunkára épülnek, amelyben nagyrészt a kutatóhelyemhez kötődő fiatalabb kutatók és leendő doktoráns hallgatók közremüködése jellemzö, amely az együttmüködő kutatócsoport hatékonyságát megsokszorozza. A hivatkozott szakirodalom azt is demonstrálja, hogy ez a közös munka a kutatócsoport tagjainak önálló kutatásait is segíti. A Tanszéken müködő „Történeti épületkutató mühely”47 mint szellemi csoportosulás ezt az összefogást mutatja be.

Ehhez kapcsolódik a módszertani áttekintés oktatásban való hasznosíthatósága: a történeti épületek megismerése, kutatása, valamint megóvásuk lehetővé tétele és ennek egyfajta módszertani megalapozása az eredmények közvetlen hasznosulását jelenti, amelynek a tehetséggondozásban, az épületkutató és a müemlékvédelmi szakembergárda nevelésében fontos szerepe van.

A tézisekben megfogalmazott konkrét tudományos eredményekből elsősorban a müemlékvédelem, illetve az építészettörténeti kutatók profitálhatnak.

Az eszterházai marionettopera kutatócsoportban végzett komplex épületkutatása tisztázta az egykor európai hírü - és ma is egyedülinek számító - marionettopera építészeti tereinek struktúráját, amely a külső helyreállításához alapvetően hozzájárult, és meghagyta annak lehetőségét, hogy - további kutatások után - a belsőt is hitelesen helyre lehessen állítani.

A protestáns templomépítészet területén végzett átfogó kutatás építészettörténeti eredménye a téma árnyaltabb bemutatásának lehetősége, és új tipológiai rendszerezés felállítása. Alapvető hasznosulási lehetőséget nyújt a müemlékvédelem területén: a felmérések során megismert - mindeddig nem kellő figyelemben részesült - értékesebb mủalkotások védettségét, múzeumi elhelyezését, illetve helyreállítását vagy restaurálását tette lehetővé. A felmérések során az épületek és történeti szerkezeteik kutatása sok gyakorlati tapasztalattal és új ismerettel bővítette tudásunkat. A feltárt problémák és az ezzel kapcsolatos figyelemfelkeltés az épületek fennmaradását segítette. A kutatás eredményei a mindmáig befejezetlen magyar müemléki topográfia céljaira is felhasználhatók.

A kutatások során érintett jelentős alkotók - elsősorban Franz Anton Hillebrandt, Pollack Mihály, Ybl Miklós - egy-egy jelentős művének kutatása, elemzése és új

\footnotetext{
${ }^{47} \mathrm{http} / / /$ doktori.bme.hu/bme_palyazat/2011/tudomanyos_muhely/Torteneti_epuletkutato_muhely_hu.htm (Utolsó megtekintés: 2016. 05. 15.)
} 
szempontok szerinti értékelése szándékunk szerint hozzájárul életmüvük egy-egy szakaszának árnyaltabb bemutatásához, ezen keresztül a magyarországi építészet európai kulturális kapcsolataira vonatkozó ismereteink bővüléséhez.

\section{A SZERZŐ TÉZISEIHEZ KAPCSOLÓDÓ 10 PUBLIKÁCIÓJA}

\section{1. témakör: Történeti épületkutatás}

1.1 .

Krähling-Halmos-Fekete 2006 Krähling János - Halmos Balázs - Fekete J. Csaba: A fertődi marionettszínház új értelmezése - az épületkutatás („Bauforschung”) és alakhü felmérés mint kutatási módszer alkalmazásával. Épités - Épitészettudomány 34 (2006) 1-2. 5-55.

1.2.

Krähling et al. 2013 Krähling János - Koppány András - Fekete J. Csaba - Halmos Balázs Józsa Anna: The marionette opera and the orangerie of Eszterháza (Fertöd, Hungary). Building archaeology methods and theoretical reconstruction. Materiali e Strutture - Problemi di Conservazione 2 (2013) 4. 75-94.

\section{2. témakör: Tipológiai rendszerezés}

2.1 .

Krähling 2004

Krähling János: Evangélikus templomok a mai Magyarországon. (Veszendő templomaink, III.) Nemzeti Tankönyvkiadó, Budapest 2004.

2.2 .

Krähling 2015

Krähling, János: The Protestant Church Architecture of East-Central Europe in the Seventeenth to Eighteenth Centuries - From Medieval Heritage to New Spatial Solutions - An Overview. In: Harasimowicz, Jan (szerk.): Protestantischer Kirchenbau der Frühen Neuzeit in Europa: Grundlagen und neue Forschungskonzepte. Schnell und Steiner, Regensburg 2015. 131-146.

\section{3. témakör: Építészet és identitás}

3.1.

Krähling-Nagy 2011

Krähling János - Nagy Gergely Domonkos: Príspevok k výskumu architektoktonického dedičstva slovenských evanjelikov v Uhorsku - tradícia

3.2. Barokovej centrality. Architektúra \& Urbanizmus XLV (2011) 1-2. 2-19.

Krähling 2013

Krähling, János: Architektur und Gedächtnisgemeinschaft: Die Kirchen der evangelisch-lutherischen Deutschen im Komitat Tolnau in Ungarn. In: Fata Marta (szerk.): Migration im Gedächtnis: Auswanderung und Ansiedlung im 18. Jahrhundert in der Identitätsbildung der Donauschwaben. Institut für donauschwäbische Geschichte und Landeskunde - Schriftenreihe 16. Franz Steiner Verlag, Stuttgart 2013. 169-186.

\section{4. témakör: Újítás és hagyomány}

4.1.

Krähling-Nagy 2013 Krähling János - Nagy Gergely Domonkos: A nagyváradi székesegyház Hillebrandt-féle centrális tervei. Ars Hungarica 39 (2013) Supplementum $81-88$. 
4.2.

Krähling 2009
Krähling, János: „La chiesa evangelica di Pest di Mihály Pollack.” In: Giuliana Ricci - Giovanna D’Amia (szerk.): Leopoldo Pollack e la sua famiglia: Cantiere, formazione e professione tra Austria, Italia e Ungheria. Milano. Istituto per la Storia dell'Arte Lombarda 2009. 187-194 + 4p. 9 ábrával. ISBN: 978-88-9035-102-0

\section{5. témakör: Építészeti lelemény és mintakövetés}

5.1 .

Krähling 2007

5.2 .

Krähling 2014
Krähling János: Romantika és evangélikus templomépítészet. In: Buda Attila - Ritoók Pál (szerk.): A fóti templom és a romantika épitészete. Terc Kiadó, Budapest 2007. 27-31.

Krähling, János: Die evangelische Kirche von Miklós Ybl in Kecskemét. Acta Historiae Artium 55 (2014) 177-192.

\section{A TÉZISFÜZETBEN HIVATKOZOTT TOVÁBBI SZAKIRODALOM}

Assmann 2000
Boato - Pittaluga 2000

Bibó 1984-1985

Bibó 2013

Bíró 1932

Brüske 2001

Cramer 1993

Daragó-Bakonyi 2015

Dávid 1978

De Jonge-Van Balen 2002

Eißing 2005
Assmann, Jan: Religion und Kulturelles Gedächtnis. Zehn Studien. C.H. Beck Verlag, München 2000.

Boato, Anna - Pittaluga, Daniela: Building archaeology: a non-destructive archaeology. In: 15th World Conference on non-destructive testing, Rome (Italy) - 15-21 October 2000. Proceedings, AIPnD, 2000, compact disc, file IDN 365. http://www.ndt.net/article/wcndt00/papers/idn365/idn365. htm (Utolsó megtekintés: 2015. 05. 10.)

Bibó I.: Der protestantische Kirchenbau in Ungarn um 1800. Teil I-II. Mitteilungen der Gesellschaft für Vergleichende Kunstforschung in Wien 36/3 (1984) 1-4. und 37/1-2 (1985) 1-5.

Bibó István: Klasszicizmus 1800-1840. Protestáns templomépítészet. In: Sisa József (szerk.): Magyar müvészet a 19. században-épitészet és iparmüvészet. MTA Bölcsészettudományi Kutatóközpont - Osiris Kiadó, Budapest 2013. 134-150.

Bíró József: Nagyvárad barokk és neoklasszikus müvészeti emlékei. Centrum, Budapest 1932.

Brüske, Gunda: Die Liturgie als Ort des kulturellen Gedächtnisses. Anregungen für ein Gespräch zwischen Kulturwissenschaften und Liturgiewissenschaften. Liturgisches Jahrbuch 51 (2001) 151-157.

Cramer, Johannes: Handbuch der Bauaufnahme. Deutsche Verlags-Anstalt, Stuttgart $1993^{2}$.

Daragó László - Bakonyi Dániel: Report about the Architectural survey of the Parish Church of the Settlement of Sanvignes-les-Mines. Periodica Polytechnica Architecture 46 (2015) 1. 6-16.

Dávid Ferenc: A falkutatások szerepe a müemléki helyreállításokban. In: $A z$ Egri Nyári Egyetem elöadásai 1977. Budapest, é.n. [1978] 73-82.

De Jonge, Krista - Van Balen, Koen (szerk.): Preparatory Architectural Investigation in the Restoration of Historical Buildings. Leuven Universtity Press, Leuven 2002.

Eißing, Thomas: Zur Anwendung der Dendrochronologie in der Bauforschung: Einige kritische Anmerkungen. In: Cramer, J. - Goralczyk, 
Feld 1999

Feld-Klein 2004

Fiorani 2004

Gerkan 1924

Gerő 1958

Groat-Wang 2002

Großmann 1993

Großmann 2010

Hajnóczi 1956

Halmos-Marótzy 2015

Haris 2004

Haris 2015

Horler 1981

Kelényi 1976

Kemény-Gyimesy 1944

Komárik 1994
P. - Schumann, D. (Hrsg.): Bauforschung - eine kritische Revision. Lukas Verlag, Berlin 2005. 297-328.

Feld István: Kutatás-dokumentálás-rekonstrukció. In: Müemlékvédelmi Szemle 1999/1-2. sz. 27-56.

Feld, István - Klein, Ulrich (szerk.): Bauforschung und Hausforschung in Ungarn. (Jahrbuch für Hausforschung Band 47. Bericht über die Tagung des Arbeitskreises für Hausforschung e.V. in Székesfehérvár [Stuhlweißenburg], Ungarn, vom 19-23. Juni 1996.) Arbeitskreis für Hausforschung - Jonas Verlag, Marburg 2004.

Fiorani, Donatella: Restauro architettonico e strumento informatico. Liguori Editore, Napoli 2004.

Gerkan, Armin von: Die gegenwärtige Lage der archäologischen Bauforschung in Deutschland. Zentralblatt der Bauverwaltung 44 (1924) Nr. 44 (29. Oktober 1924), S. 375ff. (Megjelent: Von Antiker Architektur und topographie. Gesammelte Aufsätze. Hrsg. von Erich Boehringer. Stuttgart 1959.)

Gerő László: Épitészeti müemlékek feltárása, helyreállitása és védelme. Müszaki Könyvkiadó, Budapest 1958.

Groat, Linda - Wang, David: Architectureal Research Methods. John Wiley\&Sons, New York 2002.

Großmann, G. Ulrich: Einführung in die historische Bauforschung. Wissenschaftliche Buchgesellschaft, Darmstadt 1993. 203+55 p.

Großmann, G. Ulrich: Einführung in die historische und kunsthistorische Bauforschung. Wissenschaftliche Buchgesellschaft, Darmstadt 2010. $167 \mathrm{p}$.

Hajnóczi Gyula: Mủemlékfelmérés. In: Az Épitőipari Müszaki Egyetem Tudományos Közleményei. I. kötet 6. sz. Budapest 1956.

Halmos Balázs - Marótzy Katalin: Müemlék, rajz, kutatás. A Budapesti Müszaki és Gazdaságtudományi Egyetem Épitészettörténeti és Müemléki Tanszékének felmérései és kutatásai a gyulafehérvári Szent Mihályszékesegyházon 2000-2013. - Monument, drawing, research. Surveys, explorations and research by Budapest University of Technology and Economics, Department for History of Architecture and of Monuments regarding the Saint Michael's Cathedral of Alba Iulia 2000-2013. Országos Müszaki Információs Központ és Könyvtár Budapesti Müszaki és Gazdaságtudományi Egyetem, Budapest 2015.

Haris Andrea: Múemlék épületek kutatásának módszertana és annak változása. Müemlékvédelem XLVIII (2004) 5. 297-302.

Haris Andrea: Műemléki érték és az értékleltár. Müemlékvédelem LIX (2015) 3. 156-160.

Horler Miklós: Mủemlékvédelmünk elvei és módszerei. ÉpitésÉpitészettudomány XIII (1981) 1-2. 63-84.

Kelényi György: Franz Anton Hillebrandt. Akadémiai Kiadó, Budapest 1976.

Evangélikus Templomok. Készült az Országos Luther Szövetség munkaközösségében. Szerkesztők: Kemény Lajos - Gyimesy Károly. Athenaeum, Budapest 1944.

Komárik Dénes: Budapesti lakóépületek történeti feltárásának metodikája. In: Müemlék lakóházak. Az Egri Nyári Egyetem előadásai 1994. június 21-28. (A kiadásért felel: Román A.) OMVH-Heves m. TIT h. n. [Budapest-Eger] 1994. 30-37. 
Krähling 1993

László 2005

Mader 1987

Mader 2005

Marosi 1985

Marótzy 2005

Mentényi 2009

Mezős 2008

Morsbach 1990

Raffay 1944

Redtenbacher 1879

Schirmer 1995

Schmidt W 1989

Schuller 1990

Schuller 2002

Sturm 1718

Tóth 1973
Krähling János: Evangélikus templomépítészet a Dél-Dunántúlon - egy hagyományos templomforma kialakulása a XVIII. század végén. Kandidátusi értekezés. (Kézirat.) Budapest 1993. 150 p. (220 p. függelékkel.)

László Csaba: Épületkutatási módszertanról másként. (Hozzászólás Haris Andrea: Mủemlék épületek kutatásának módszertana és annak változása című cikkéhez. In: Müemlékvédelem 2004/5. 297-302.) Müemlékvédelem XLIX. (2005) 2. 106-108.

Mader, Gert: Bauaufnahme als Forschungsmethode und Bestandsdokumentation des Denkmalpflegers. In: Schmidt, Hartwig (szerk.): Bauaufnahme - Bestandsuntersuchung und Dokumentation Historischer Bauwerke. (8. Kolloquium des Sonderforschungsbereiches 315) Arbeithefte des Sonderforschungsbereiches 315 „Erhalten historisch Bedeutsamer Bauwerke" Heft 7. Universität Karlsruhe 1987. 45-70.

Mader, Gert Thomas: Angewandte Bauforschung. (Materialien aus dem Institut für Baugeschichte, Kunstgeschichte, Restaurierung mit Architekturmuseum Technische Universität München, Fakultät für Architektur) Verlag Das Beispiel, Darmstadt 2005. 171 p.

Marosi Ernő: Mủemlékkutatás és művészettörténet-írás. Müvészet 1985/8. 2-7.

Marótzy Katalin: Mintakövetés és invenció a XIX. század második felének budapesti építészetében. Épités - Épitészettudomány 33 (2005) 1-2. 27-44. Mentényi Klára: Müemlékvédelemről és épületkutatásról - másképpen. Müemlékvédelem LIII (2009) 3. 146-152.

Mezős Tamás: Épületkutatás - Bauforschung - Building Archaeology Archéology du Bati. Müemlékvédelem LII (2008) 6. 376-388.

Morsbach, Peter (szerk.): Der Dom zu Regensburg - Ausgrabung, Restaurierung, Forschung. Verlag Schnell\&Steiner, München-Zürich 1990. D. Raffay Sándor: Az evangélikus egyház liturgiája. In: Evangélikus Templomok. Készült az Országos Luther Szövetség munkaközösségében. Szerkesztők: Kemény Lajos - Gyimesy Károly. Athenaeum, Budapest 1944. 473-478.

Redtenbacher, Rudolf: Wie lernt man und wie lehrt man die Baukunst? Deutsche Bauzeitung 13 (1879) 39. 197-199; 41. 207-210; 43. 217-220. Változatlan utánnyomás In: Ralph Johannes (szerk.): Entwerfen Architekturausbildung in Europa von Vitruv bis Mitte des 20. Jahrhunderts. Junius Verlag, Hamburg 2009. 526-543.

Schirmer, Wulf: Das Bauwerk als Quelle. Architectura 24. 1994 (1995) 1/2 (Das Bauwerk als Quelle), S. 323.

Schmidt, Wolf: Das Raumbuch. (=Arbeitsheft Nr. 44 des Bayerischen Landesamts für Denkmalpflege.) München 1989.

Schuller, Manfred: Bauforschung. In: Der Dom zu Regensburg. Ausgrabung, Restaurierung, Forschung. Verlag Schnell\&Steiner, München-Zürich 1990 (3. kiadás) 168-223.

Schuller, Manfred: Building Archaeology. Monoments and Sites VII. Edited by ICOMOS, h. n. [München] 2002.

Sturm, Leonhard Christoph: Vollständige Anweisung alle Arten von Kirchen wohl anzugeben.... Augspurg, 1718.

Tóth Sándor: Régészet, mủemlékvédelem, történelem. Épités- Épitészettudomány V (1973) 617-630. 


\title{
BUILDING ARCHAEOLOGY AND ARCHITECTURAL HISTORY - RESEARCH METHODOLOGY AND RESULTS OF SOME EARLY MODERN AND $19^{\mathrm{TH}}$ CENTURY BUILDING TYPES
}

\section{HABILITATION THESIS}

\begin{abstract}
Summary
The link between historic building research and the history of architecture has already attracted many researchers. In my theses I intend - by reviewing and criticizing the interrelationships of the domestic and international literature - to summarize, interpret, present and to point out the results obtained through the use of the methodology and principles elaborated for the research of Early Modern and $19^{\text {th }}$ century buildings.

Five theses based on my chosen ten publications show the different scales and interpretations of architectural research on the example of five different research issues. The methodology of historic building research plays an important role in all five selected examples, through its interdisciplinary approach, through the analysis of historic written and image sources and the closely related building survey based on principles used in building archaeology. The paper aims at presenting different approaches from a smaller-scale typological and topographic research capable of covering regional and territorial architectural phenomena, to address cultural identity issues affecting the social aspects of architecture.
\end{abstract}

Keywords: building archaeology, Bauforschung, Mihály Pollack, Miklós Ybl, Oradea Cathedral, protestant church architecture 